\title{
SAMOMORILNOST V POLICIJI
}

Povzetek Znanstvene ugotovitve kažejo na veliko verjetnost ponovitve samomora policista, ki je enkrat že poskušal storiti samomor, in problematizirajo zanesljivost psiholoških pregledov glede odločanja o omejitvi dostopa do orožja. Predstavljena je dobra praksa spoprijemanja s problematiko samomorilnosti med pripadniki Slovenske vojske, ki bi lahko pomenila vzorec za izvajanje ukrepov za zaščito policistov. Od leta 1991 se število samomorov v policiji postopoma zmanjšuje, kljub temu pa se od leta 2009 do 2020 zmerno povečuje, predvsem zaradi številčnejših samomorov v obdobju od leta 2018 do 2020. S statistično metodo Hi-kvadrat smo ugotovili, da številčnost samomorov v obdobju od leta 2018 do 2020 ni statistično značilna glede na obdobje od leta 2009 do 2017 oziroma je mejna.

Ključne

Samomor, samomorilnost, policija.

besede

Abstract The current scientific findings show a high probability of a recurrence of a suicide attempt with a police officer who has already tried to commit suicide. They problematize the reliability of psychological examinations for limited firearm access. The article presents good practice in confronting the issue of suicide among members of the Slovenian Armed Forces, which could serve as a model for the police officer protection measures. Since 1991, the number of suicides in the police has been gradually decreasing. However, in the period 2009-2020, the number has been moderately increasing, mainly due to the higher number of suicides in the period 2018-2020. With the statistic method Chi-squared test, we have established that the number of suicides in the period 2018-2020 is not statistically significant in comparison to the period 2009-2017, or its significance is borderline.

\section{Key words Suicide, suicidality, police.}


Uvod Samomorilnost v policiji je fenomen, ki že od nekdaj obstaja v strukturi policije, ukvarjanje s to problematiko pa je razvidno iz objavljenih strokovnih in znanstvenih člankov in publikacij. Značilna je specifičnost raziskovalnega področja, ki se deloma razlikuje od problematike samomorilnosti splošne populacije.

V članku smo opravili analizo in pregled aktualnih tujih znanstvenih spoznanj na področju problematike samomorilnosti $\mathrm{v}$ policiji in dognanja aplicirali na problematiko v slovenski policiji. Namen tovrstnih tujih raziskav in obenem tudi naše analize je ugotoviti trenutne trende, značilnosti samomorov v policiji ter na podlagi teh izsledkov predvideti prihodnje trende, na podlagi analize trenutnega stanja ter zbranih lastnih in tujih izkušenj pa predlagati primerne preventivne in kurativne ukrepe. Pri raziskavi in izvedbi posamičnih analiz smo si pomagali s splošnima premisama našega raziskovanja in podrobnejšim vpogledom v posamezna področja, povezana z raziskavo. Leta 2017 je bila izvedena obsežna analiza pojava samomorilnosti v slovenski policiji, ki je vključevala analizo primerov samomorov od leta 1948 do 2016, uradne podatke o samomorih pa je takrat posredovala policija (Blažina, 2017). Raziskava je pokazala, da se je količnik samomorilnosti ${ }^{1}$ v obdobju po osamosvojitvi leta 1991 konstantno zniževal tako v splošni populaciji Slovenije kot tudi v policiji (Blažina, 2017, str. 353-354). Naša analiza prikazuje in povzema tudi nekatere ugotovitve ter dobre prakse preprečevanja samomora med pripadniki Slovenske vojske (v nadaljevanju SV), ki so v času naborniškega sistema in pozneje med uvedbo profesionalizacije SV pripomogle $\mathrm{k}$ zmanjšanju tovrstne problematike in bi bile $\mathrm{v}$ nekaterih segmentih primerne tudi za redukcijo obsega problematike samomorilnosti v slovenski policiji.

\section{METODOLOGIJA}

V pripravah na izvedbo raziskave so nas v širšem smislu zanimali statistično gibanje pojava samomorilnosti $\mathrm{v}$ policiji ter pripravljenost in odzivanje policije na pojav samomorilnosti v njenih vrstah. Tako smo si zastavili dve premisi raziskovanja, in sicer nas je zanimalo, ali se številčnost samomorov v zadnjih desetih letih povečuje ali manjša in koliko je policija pripravljena na spoprijemanje s problematiko samomorilnosti v svojih vrstah. Posebej nas je zanimalo število primerov samomora v policiji od leta 2009 do 2020 in kakšne ukrepe je ta uvedla ter jih še uvaja za evidentiranje, preprečevanje, zmanjšanje ali obravnavo samomorov in samomorilno ogroženih policistov. Podrobneje nas je zanimalo tudi, kako in koliko policija upošteva aktualne domače in tuje smernice ter ugotovitve s področja ukrepov proti samomorilnosti. Da bi konkretneje preverili uspešnost spoprijemanja s problematiko samomorilnosti v policiji, smo opravili primerjavo urejenosti področja evidentiranja, preprečevanja in spoprijemanja s samomori v Slovenski vojski.

Količnik samomorilnosti je izračunan kot razmerje med številom policistov, zaposlenih v policiji v tekočem letu, in številom samomorov $v$ policiji $v$ istem letu ter $v$ sklepnem računu predstavlja podatek o številu samomorov na 100.000 prebivalcev v konkretni obravnavani skupini, torej o številu samomorov na 100.000 prebivalcev $v$ tekočem letu. 
Za izvedbo raziskave smo opravili študijo in primerjavo podatkov iz razpoložljive sodobne literature, objavljenih sodobnih znanstvenih člankov in domačih normativnih virov, ki se nanašajo na obravnavano področje raziskovanja. Podatke smo pridobili iz uradnih virov policije in Slovenske vojske ter Sindikata policistov Slovenije (SPS). Zbrane podatke smo sistematično uredili in jih za izvedbo raziskave statistično analizirali.

\section{PRIMERJAVA Z DRUGIMI POLICIJAMI IN MOŽNOST PREPREČEVANJA SAMOMOROV V POLICIJI}

Preučevanje samomorilnosti med pripadniki varnostnih organov je najbolj prisotno $\mathrm{v}$ zahodnih državah, predvsem $\mathrm{v}$ ZDA in državah zahodne Evrope. V zadnjih petih letih so bile izvedene znanstvene raziskave o pojavnosti samomorilnosti $\mathrm{V}$ policiji oziroma varnostnih organih in pridobljene pomembne ugotovitve, ki jih predstavljamo v nadaljevanju.

\subsection{Združene države Amerike}

Glede na objavljene rezultate raziskave o pojavnosti samomorov s strelnim orožjem med policisti in preostalim prebivalstvom so v ZDA samomori, storjeni s strelnim orožjem, najpogostejši način izvršitve samomora. Tako so $\mathrm{v}$ okviru projekta »HOPE²« v ZDA med splošno populacijo leta 2017 ugotovili približno 60 odstotkov vseh storjenih samomorov z orožjem. V ameriški zvezni državi Utah je ta delež med splošno populacijo še večji, in sicer okrog 80 odstotkov (Barber et al., 2019, str. 1695). Zaradi uspešnejšega preventivnega pristopa $\mathrm{k}$ zmanjšanju te problematike je bila v tej zvezni državi izvedena obsežna analiza stanja in vzročnosti, predlagani in izvedeni so bili tudi ukrepi. V raziskavi so ugotovili nekaj zanimivih dejstev, ki se nanašajo na splošno populacijo in bodo v pomoč pri splošnem razumevanju fenomena samomora. Ugotovitve, ki so zelo pomembne pri načrtovanju in izvajanju preventivnih ukrepov ter razumevanju samomora, so predvsem ugotovljen interval med samomorilno mislijo in izvedbo samomora, ki naj bi bil v povprečju deset minut ali manj. Študija je bila namreč izvedena tudi med posamezniki iz splošne populacije, ki so že enkrat poskušali storiti samomor z ustrelitvijo. Glede na omenjeno okoliščino je v trenutku obstoja samomorilne misli bistveno tudi to, ali je posamezniku na voljo orožje ali sredstvo za realizacijo samomora. Na podlagi statističnega preučevanja primerov samomora je bila ugotovljena povezava med poskusi samomorov in storjenimi samomori, saj so posamezniki, ki so v preteklosti že poskušali storiti samomor, nagnjeni k storitvi in dokončni realizaciji samomora, in sicer v kar 90 odstotkih. Zanimiva je tudi ugotovitev, da so posamezniki v času storitve samomora s strelnim orožjem orožje posedovali legalno in bi bili v 92 odstotkih psihično in fizično sposobni za posest orožja v primeru zdravniškega pregleda. Le 8 odstotkov oseb, ki so umrle zaradi samomora, bi bilo v primeru zdravniškega pregleda na dan storitve samomora lahko prepoznanih kot psihično neprimerni posestniki strelnega

\footnotetext{
2 Project HOPE - The People-to-People Health Foundation je nevladna organizacija $v$ ZDA, ki se ukvarja z vprašanji zdravstvene zaščite v ZDA (https://www.projecthope.org/).
} 
orožja zaradi psihičnih motenj ali bolezni. Glede na omenjeno sta za načrtovanje preventivnih ukrepov bistvenega pomena opazovanje in takojšen odziv sorodnikov in oseb, ki so blizu morebitnemu samomorilcu, da njegovo stisko prepoznajo in osebi pravočasno pomagajo, tudi z odtegnitvijo sredstev za storitev samomora in $\mathrm{s}$ čimprejšnjo zdravniško oziroma psihološko pomočjo. Pomembna je tudi izmenjava informacij med upravnimi organi in zdravstvenimi ustanovami o posameznikih s samomorilnimi nagnjenji, da se jim še pravočasno omeji dostop do sredstev, $s$ katerimi bi lahko storili samomor, $\mathrm{v}$ tem primeru z odvzemom legalnega strelnega orožja (Barber et al., 2019, str. 1695, 1701).

V ZDA je bila leta 2018 izvedena in objavljena metaanaliza objavljenih člankov o samomorilnosti med policisti. V okviru projekta je bilo analiziranih skupno 97 dokumentov in 44 že objavljenih člankov za obdobje od leta 1997 do 2016. Študija razpoložljivih članov in dokumentov, ki vsebujejo podatke o samomorilnosti med policisti v ZDA in drugih državah, ugotavlja, da ni mogoče z gotovostjo ugotoviti in določiti enotnih značilnosti korelacije samomorov v policiji in samomorov med splošno populacijo. Količnik samomorilnosti med policisti je po državah različen in se giblje od večjega do manjšega količnika glede na splošno populacijo. Kot glavni stresor med policisti, ki lahko vodi do samomora, so v študijah ugotavljali organizacijske dejavnike v policiji, obravnavanje stresnih dogodkov med službo, odklanjanje strokovne pomoči, kar je povezano s stigmatiziranjem »šibkosti« in policijsko subkulturo. Čezmerno uživanje alkohola in težave v družinskem življenju $\mathrm{v}$ analizi povezujejo $\mathrm{z}$ naravo stresnega policijskega dela in izmenskim delom (Violanti, Owens, McCaniles, Fekedulegn in Andrew, 2018, str. 141, 164).

\subsection{Portugalska}

V projektu, ki so ga leta 2019 in 2020 izvedli študenti in profesorji na Fakulteti za psihologijo Univerze v Portu na Portugalskem, izhaja, da je kritičen dejavnik pri povečanem tveganju za samomor med policisti prav neomejen in takojšen dostop do strelnega orožja. Primerjali so tudi količnik samomorilnosti med splošno (primerjalno) populacijo in portugalskimi policisti v obdobju od leta 2005 do 2014 ter ugotovili, da je bilo v omenjenem obdobju med portugalskimi policisti storjenih skupaj 39 samomorov, od tega 34 s strelnim orožjem oziroma 30 storjenih s službenim strelnim orožjem. Količnik samomorilnosti je tako v portugalski policiji za omenjeno obdobje 20,6 samomora na 100.000 prebivalcev, medtem ko je bil v istem obdobju med splošno populacijo količnik samomorilnosti 13,9 samomora na 100.000 prebivalcev. Kot pomanjkljivost izpostavljajo premajhen statistični vzorec, edina oseba ženskega spola, ki je storila samomor, pa je bila iz raziskave izključena. Kot pomanjkljivost izpostavljajo tudi pomanjkanje podatkov o samomorih med upokojenimi policisti in policisti, ki so bili odpuščeni (Costa, Passos in Queirós, 2019). 


\subsection{Italija}

V Italiji je bila izvedena podrobna analiza samomorov med policisti državne policije (Polizia di Stato) za obdobje od leta 1995 do 2017, pri čemer so pridobljene podatke primerjali s splošno primerjalno populacijo (moški, mlajši od 65 let). Glede na analitično oziroma statistično obdelane podatke je v tem obdobju zaradi samomora v Italiji umrlo 271 policistov. Povprečni količnik samomorilnosti med italijanskimi policisti in policistkami je bil v tem obdobju (1995-2014) 11,78, v obdobju od leta 1995 do 2017 pa 11,62. Med splošno italijansko populacijo je bil količnik samomorilnosti v obdobju od leta 1995 do 2014 le 4,67 (moški in ženske skupaj). V omenjenem obdobju od leta 1995 do 2014 je bil količnik samomorilnosti med policisti moškega spola 12,67, med italijansko splošno moško populacijo pod 65 let pa 7,44. Kot zanimivost so ugotovili, da je stopnja samomorilnosti med italijanskimi policistkami 2,7-krat višja od primerjalne splošne ženske populacije v Italiji, vendar gre pri tem za analizo majhnega števila podatkov. Stopnja samomorilnosti se je vidno zmanjšala v obdobju od leta 1995 do 2007, nato pa bila v konstantnem stabilnem trendu do leta 2017. Celotno obdobje od leta 1995 do 2017 kaže na trend upadanja številčnosti samomora v italijanski državni policiji. Pri izvedbi analize so uporabili javno dostopne podatke italijanskega statističnega urada ISTAT $^{3}$ ter podatke o posameznih policistih, ki so storili samomor, in okoliščinah storitve samomora, ki jim jih je skupaj s splošnimi podatki o vsakoletnem številu vseh policistov državne policije posredovalo vodstvo italijanske državne policije (Grassi et al., 2019, str. 18, 23).

\section{UKREPI ZA PREPREČEVANJE SAMOMORILNOSTI V SLOVENSKI VOJSKI V ČASU UVEDBE NABORNIŠKEGA SISTEMA IN OBDOBJU PROFESIONALIZACIJE}

\subsection{Obdobje uvedbe naborniškega sistema}

Slovenska vojska se je v času po osamosvojitvi države oziroma med uvedbo naborniškega sistema spoprijemala $\mathrm{s}$ problematiko samomorov med svojimi pripadniki, pri čemer je bila še posebno pereča problematika pojavov samomorilnih teženj in primerov v času obstoja naborniškega sistema SV (Plemenitaš - Fuchs, 2003, str. 30-32). Opravljena je bila strokovna in poglobljena analiza, ki jo je avgusta 1997 v SV izvedel Operativni oddelek Generalštaba SV (v nadaljevanju GŠSV), z naslovom Samomorilna dejanja v Slovenski vojski v obdobju od leta 1991 do julija 1997. V analizi so ugotovili, da je problematika samomorilnih teženj med pripadniki stalne sestave SV in psihološko nefiltriranimi naborniki precej uravnotežena, zaradi česar predlagajo izvedbo ukrepov za psihološko filtriranje kandidatov za zaposlitev v SV in pravilno razporejanje na delovne dolžnosti, ki so osebnostno primerne za vsakega posameznika. Ugotovili so tudi vzroke za približno polovico vseh izvršenih samomorov v SV, pri čemer prednjačijo predvsem neorganizacijski vzroki, povezani z zasebnim življenjem posameznika (ločitev od partnerja, prezadolženost, psihične

3 ISTAT-podatki, objavljeni na spletni strani http://www.istat.it/it/archivio/suicidi. 
motnje ali bolezni), organizacijski vzroki, povezani z delom v SV in obremenitvami vojakov, pa na to problematiko niso imeli bistvenega vpliva. Po izvedbi poglobljene analize GŠSV se je od avgusta 1997 do vključno leta 2002 številčnost samomorov med pripadniki SV bistveno zmanjšala, saj je bilo od leta 1991 do avgusta 1997 med pripadniki SV 38 samomorov, od avgusta 1997 do leta 2002 pa le šest (Plemenitaš - Fuchs, 2003, str. 42). SV je na podlagi analize začela za pripadnike SV izvajati intenzivno psihološko oskrbo, razvila boljšo čuječnost med njimi in izvedla ukrepe za krepitev homogenosti enot SV in pripadnosti službi ter še nekatere ukrepe, ki so vključili sodelovanje družine pripadnikov SV, in razvila skrb tudi zanje.

\subsection{Ukrepi Slovenske vojske pri preprečevanju pojava samomorilnosti med vojaki v času od uvajanja profesionalizacije do danes}

SV je z ukinitvijo naborniškega sistema in hkratno uvedbo profesionalizacije vojakov leta 2003 ustrezno prilagodila tudi preventivno dejavnost na področju pojava samomorilnosti med vojaki SV. Glede na že opisane izvedene preventivne ukrepe, ki jih je SV že izvajala v času naborniškega sistema, je te v času od uvedbe profesionalizacije vojakov od leta 2003 naprej samo še vsebinsko dopolnjevala. Ugotovimo lahko, da se običajen povod in dejavniki za izvedbo samomora med slovenskimi policisti in vojaki nekoliko razlikujejo. Med policisti je delež organizacijskih $^{4}$ in neorganizacijskih dejavnikov samomora (pri definiciji smo upoštevali dejavnike stresa v policiji (Huselja, 2017, str. 193)) razdeljen nekako na polovico, med vojaki pa je v večini primerov med vojaki razlog v neorganizacijskih dejavnikih oziroma v zasebnem življenju vojaka. Zato je SV začela kompleksneje reševati to problematiko in v svoje preventivne ukrepe vključila tudi družine vojakov. Z uvedbo vodnih in četnih zaupnikov v vojaških enotah so v SV (ZSSloV, 2007) omogočili lažje ugotavljanje težav in dvignili čuječnost glede hitrega zaznavanja težav med pripadniki SV med pripadniki enot ter omogočili hitrejšo izmenjavo podatkov med moštvom in nadrejenimi (Pravila službe v Slovenski vojski, 2009, člen 9). Strokovna komisija, sestavljena iz strokovnjakov Ministrstva za obrambo, pripadnikov SV in zunanjih strokovnjakov, je leta 2011 izvedla analizo samomorov v SV od leta 1994 do 2011 in podatke črpala iz poročil o samomorih in poskusih samomorov v enotah TO/SV. Samomorov je bilo v SV v navedenem obdobju 17 in 9 poskusov storitve samomora. Med vojaškimi osebami v 79 odstotkih prevladuje samopoškodba s strelnim orožjem, samomorov, skupaj s poskusi, z obešanjem pa je bilo skupno 6 odstotkov. Na podlagi izvedenih analiz je strokovna skupina strokovnjakov z Ministrstva za obrambo in iz SV ter zunanjih strokovnjakov na podlagi ukaza načelnika Generalštaba Slovenske vojske (GŠSV), št. 812-3/2011192 z dne 12. 7. 2011, pripravila Akcijski načrt za znižanje pogostosti pojavov samomorilnega vedenja na Ministrstvu za obrambo in v Slovenski vojski, ki ga je GŠSV izdal novembra 2011 (GŠSV, 2011). Na podlagi omenjenega akcijskega načrta je GŠSV izdal še preglednico odgovornih oseb, nosilcev in rokov izvedbe posameznih ukrepov, ki je priloga osnovnega načrta. V akcijskem načrtu je strokovna

4 Tipi dejavnikov stresa $v$ policiji so organizacijski, zunanji, osebni in stresorji, povezani z opravljanjem dela (Huselja, 2017, str. 193). 
komisija analizirala preteklo obdobje glede pojavnosti pojava samomorilnosti v SV in ugotovila, da je bil količnik samomorilnosti v SV precej višji v prvem desetletju po osamosvojitvi Slovenije. Glede na posamezne podatke rezultatov opravljene analize mešane komisije strokovnjakov, ki je za SV opravila analizo, izhaja, da je v času veljavnosti naborniškega sistema v SV med njenimi pripadniki prevladoval starejši stalni in nepoklicni kader (nad 30 let), prav tako pa je bil v tem obdobju delež pripadnic ženskega spola v SV zanemarljiv. Splošno je znano, da je med osebami ženskega spola samomorilnost manj prisotna. Naslednja značilnost kadrovske strukture pripadnikov SV v tistem obdobju je predvsem psihološko nefiltrirana populacija tako stalnega sestava vojakov kot tudi nabornikov v SV. Poleg dejavnikov, ki so povezani s kadrovsko sliko SV v času veljavnosti naborniškega sistema, pa je strokovna komisija kot nekatere organizacijske dejavnike, ki so znatno vplivali na številčnost samomorov med vojaki SV, definirala predvsem lahek dostop do orožja. Iz analize izhaja, da je bilo 23,5 odstotka samomorov storjenih med stražarsko službo ali požarstvom. Komisija je tudi ocenila, da sta med socialnimi in psihološkimi vzgibi najpogostejša osamljenost in monotonost. Le 17,6 odstotka vseh evidentiranih samomorov med pripadniki SV je bilo storjenih v prostem času, in ne med službo (GŠSV, 2011, str. 7 in 9).

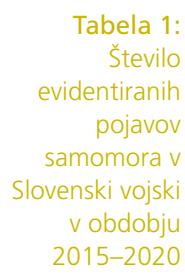

\begin{tabular}{|c|c|c|c|}
\hline Leto & $\begin{array}{c}\text { Število } \\
\text { samomorov }\end{array}$ & $\begin{array}{c}\text { Število } \\
\text { pripadnikov } \\
\text { SV }^{[1]}\end{array}$ & $\begin{array}{c}\text { Količnik } \\
\text { samomorilnosti na } \\
\mathbf{1 0 0 . 0 0 0} \text { prebivalcev }\end{array}$ \\
\hline $\mathbf{2 0 1 5}$ & 2 & 7009 & 28,5 \\
\hline $\mathbf{2 0 1 6}$ & 3 & 6875 & 43,6 \\
\hline $\mathbf{2 0 1 7}$ & 0 & 6777 & 0 \\
\hline $\mathbf{2 0 1 8}$ & 3 & 6640 & 45,1 \\
\hline $\mathbf{2 0 1 9}$ & 0 & 6402 & 0 \\
\hline $\mathbf{2 0 2 0}$ & 0 & 6321 & 0 \\
\hline Skupaj & $\mathbf{8}$ & & $\mathbf{1 9 , 5}$ \\
\hline Povprečje & $\mathbf{1 , 3}$ & $\mathbf{6 6 7 0}$ & \\
\hline
\end{tabular}

${ }^{[1]}$ Osnutek zakona o spremembah in dopolnitvah Zakona o obrambi, EVA 2020-1911-0009, stran 4

Podatki o gibanju primerov samomora med pripadniki SV v obdobju od leta 2015 do 2020 v tabeli 1 (GŠSV, 2021) kažejo, da je povprečno število samomorov v SV v omenjenih šestih letih 1,3 samomora na leto in da je povprečni količnik samomorilnosti v omenjenem obdobju 19,5 samomora na 100.000 prebivalcev. 


\section{SAMOMOR V SLOVENSKI POLICIJI - PODATKI ZA OBDOBJE OD LETA 2009 DO 2020}

Policija je že pred leti začela izvajati preventivne ukrepe, od vzpostavitve SOStelefona, zaposlitve psihologov na vsaki policijski upravi, organizacije mreže policijskih zaupnikov do začetka dela policijskega vikarja. Ukrepi policije so bili formalizirani v Pravilniku o psihološki pomoči in psihološki podpori uslužbencem policije (2013). Policiste s tovrstnimi težavami obravnava strokovna služba na MNZ, sestavljena iz psihologov in zdravstvenih delavcev, izvajajo pa se tudi terminski preventivni pregledi vseh policistov.

Podatki o samomorih v milici in policiji v obdobju od leta 1948 do 2016 so bili predstavljeni v Reviji za kriminalistiko in kriminologijo leta 2017 (Blažina, 2017, str. 338, 349). Ker za obdobje od leta 2017 naprej nismo pridobili uradnih podatkov o samomorih v slovenski policiji, nam je neuradne podatke, zbrane od svojih regionalnih predstavnikov, posredoval Sindikat policistov Slovenije (v nadaljevanju SPS). Ker gre za neuradne podatke, jih je treba povzemati in uporabljati previdno. Podatke za izračun količnikov samomorilnosti med policisti in količnike samomorilnosti med splošno populacijo smo poleg podatkov SPS (SPS, 2021) prevzeli tudi iz javno objavljenih podatkov Nacionalnega instituta za javno zdravje (NIJZ, 2017, 2018, 2020a in 2021), podatkov o številu policistov v obravnavanih letih - iz letnih poročil Policije, objavljenih na spletni strani Policije - statistika (razdelek letna poročila policije - število vseh policistov) (MNZ Policija, 2021) in znanstvenega članka, ki prikazuje gibanje in problematiko samomorov v Republiki Sloveniji od leta 1948 do 2016 (Blažina, 2017, str. 348-349).

V okviru prejetih podatkov o samomorih v policiji od leta 2017 do 2020 smo s pomočjo policijskega sindikata tokrat prvič zbrali tudi podatke o poskusih samomorov med policisti, pri čemer so v omenjenem obdobju poskušali storiti samomor štirje policisti. Od policistov, ki so od leta 2017 do 2020 izvršili samomor, sta po podatkih SPS vsaj dva policista predhodno že enkrat poskušala storiti samomor, vendar tudi po poskusu izvršitve kljub temu še naprej posedovala službeno orožje, s katerim sta samomor pozneje tudi dokončno izvršila (SPS, 2021).

Glede na obdobje povečanega količnika samomorilnosti med slovenskimi policisti v času od leta 2017 do 2020 pa kot način storitve samomora v sindikatu beležijo:

- dva samomora z obešanjem,

- pet samomorov s strelnim orožjem in dva poskusa storitve samomora,

- en samomor - skok z višine,

- en poskus samomora s hladnim orožjem,

- en poskus samomora - zastrupitev s tabletami.

Glede na podatke od leta 2009 do 2020 se v 11-letnem povprečju kaže pogostost samomorov v policiji predvsem v letih 2018, 2019 in 2020 (tabela 2). Zaradi 
omenjenega dejstva bomo v nadaljevanju še posebej pozorno analizirali podatke o samomorilnosti za zadnje triletno obdobje, od leta 2018 do 2020. Ugotovili smo namreč, da je v obdobju od leta 2017 do vključno 2020 samomor izvršilo skupno osem policistov - to je povprečno dva samomora na leto, štirje pa so poskusili storiti samomor. V obdobju od leta 2009 do 2016 je samomor naredilo skupaj deset policistov oziroma na leto povprečno 1,2 policista, podatkov o poskusih samomora v tem obdobju pa nimamo. Glede na ugotovljen desetletni trend konstantnega upadanja količnika samomorilnosti med slovensko splošno in moško populacijo v obdobju od leta 2009 do vključno 2019 (Roškar, 2020) smo glede na predstavljene podatke v policiji priča dvigu količnika v zadnjih enajstih letih (2009-2020) (graf 2) in predvsem opaznemu dvigu količnika v zadnjih štirih letih, od leta 2017 do 2020 (graf 1). Obenem v istem obdobju opažamo skoraj izenačenje enajstletnega (20092020) količnika samomorov v slovenski policiji $(20,4)$ in povprečnega količnika slovenske splošne populacije $(20,2)$. Količnik samomorilnosti med moško splošno populacijo $(31,8)$ je $\mathrm{v}$ obdobju od leta 2009 do 2020 znatno višji kot ta v policiji $(20,4)$.

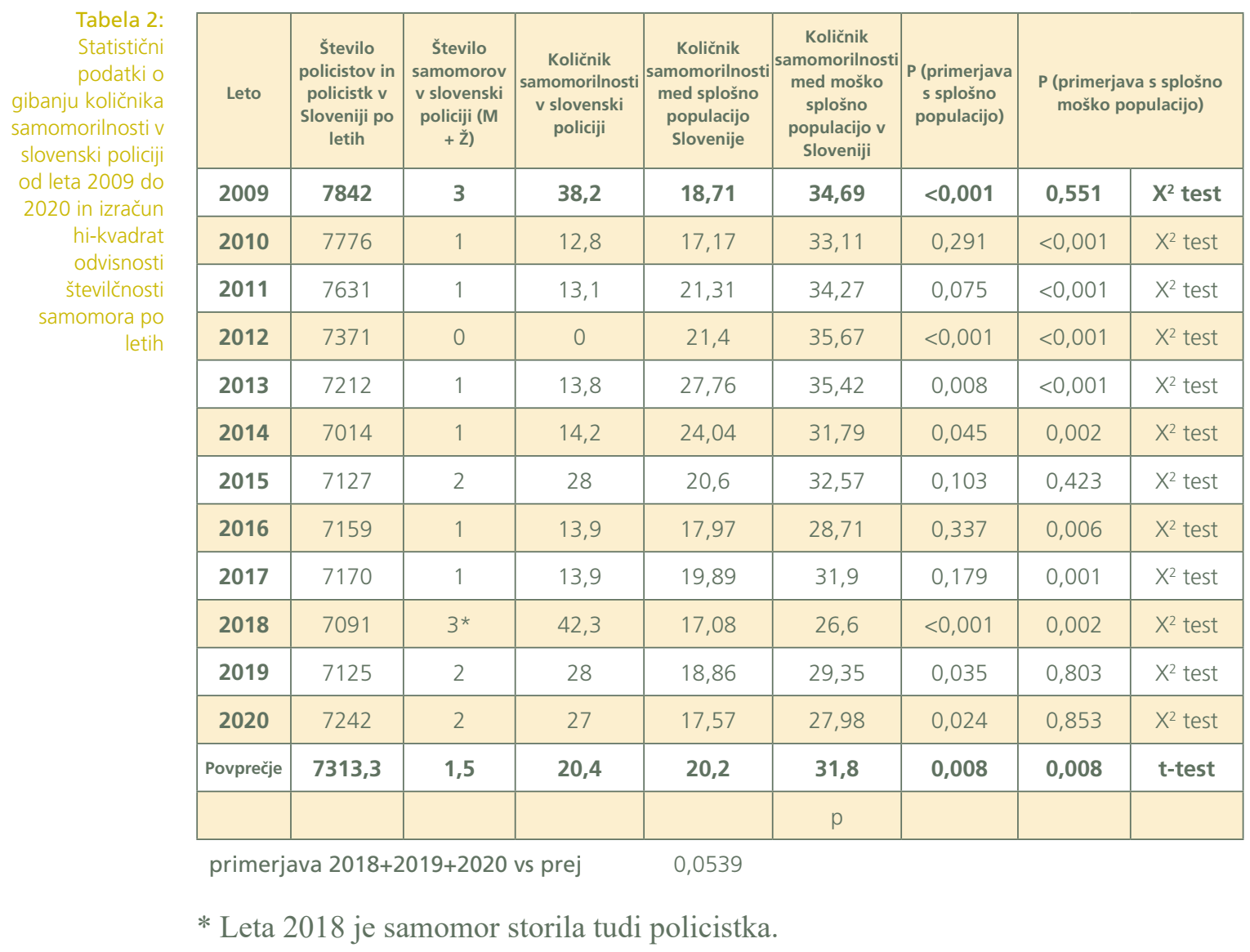


Graf 1:

Pregled

številčnosti

samomorov v

Slovenski vojski

in policiji v

obdobju od leta

2015 do 2020

\section{Linearni prikaz gibanja številčnosti samomorov v SV in Policiji (2015-2020)}

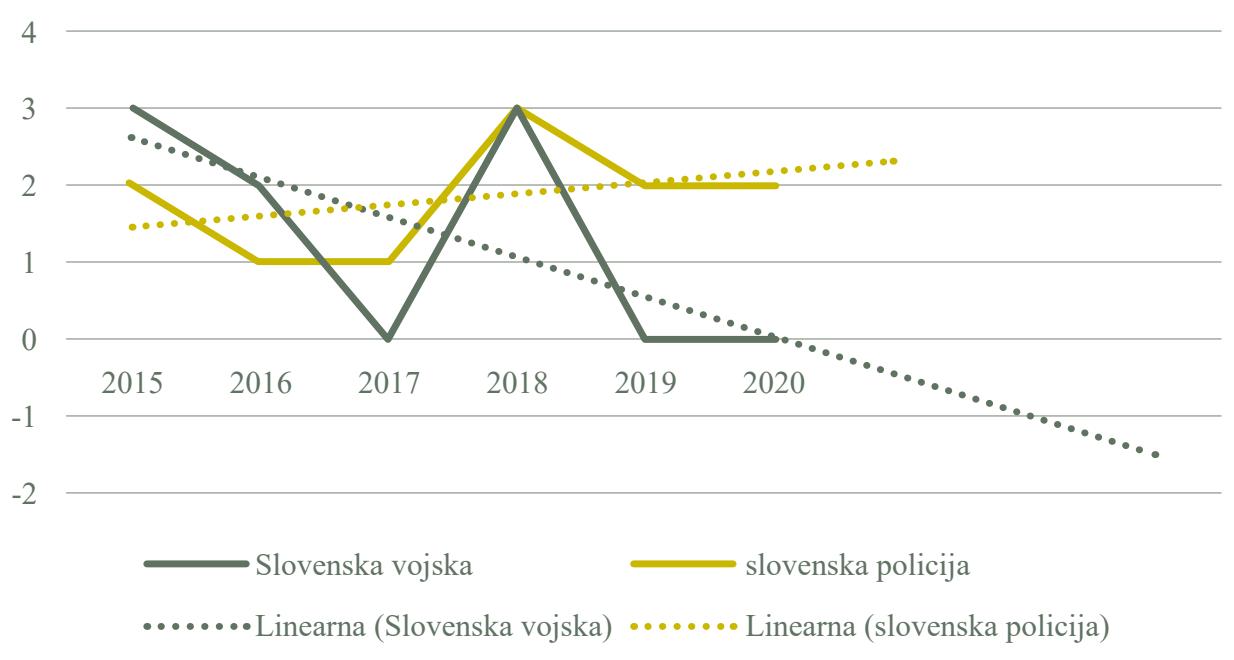

Statistika samomorov v slovenski policiji 2009-2020

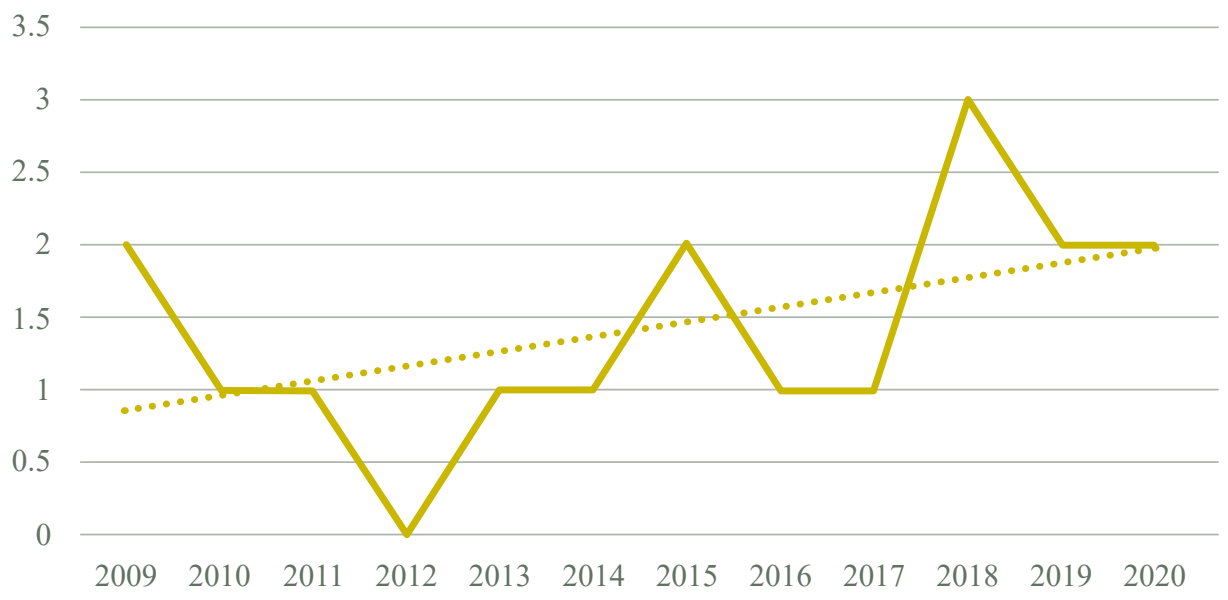

Za testiranje razlik (statistično značilne odvisnosti) v količniku samomorilnosti v policiji in med splošno populacijo za vsako koledarsko leto posebej smo uporabili 
statistično metodo hi-kvadrat test ${ }^{5}$. V tabeli 2 sta prikazana p-vrednost, ki se nanaša na primerjavo s splošno populacijo (predzadnji stolpec), in p-vrednost, ki se nanaša na primerjavo s splošno moško populacijo (zadnji stolpec). Ugotovimo, da je bil v primerjavi s splošno populacijo indeks samomorilnosti v policiji statistično značilno višji v letih 2009, 2014, 2018, 2019 in 2020, v letih 2012, 2016, 2017 pa statistično značilno nižji. V primerjavi s splošno moško populacijo je količnik samomorilnosti statistično značilno višji leta 2018, nižji pa v letih od 2010 do 2014, 2016 in 2017. Primerjava povprečnega količnika $\mathrm{v}$ policiji in splošni populaciji s t-testom za neodvisna vzorca ne pokaže statistično značilnih razlik $(\mathrm{p}=0,949)$. So pa te razlike statistično značilne, ko primerjamo količnik samomorilnosti pri policistih in $\mathrm{v}$ slovenski moški populaciji $(\mathrm{p}=0,008)$. Količnik samomorilnosti je v proučevanem obdobju v policiji statistično značilno nižji od tistega med moško splošno populacijo. Primerjava količnikov v letih 2018 in 2020 ter tistih v obdobju od leta 2009 do 2017 pokaže, da med časovnima obdobjema ni statistično značilnih razlik v količniku samomorilnosti $(p=0,0539)$, pri čemer lahko opazimo, da gre za minimalne mejne statistične vrednosti ${ }^{6}$. Glede na podatke, prikazane v grafu 2, lahko sklepamo, da se število samomorov v slovenski policiji v zadnjih enajstih letih (2009-2020) povečuje. Glede na raziskavo iz leta 2017, v kateri so analizirali gibanje samomorilnosti v policiji od leta 1995 do 2016 (Blažina, 2017, str. 349), je bilo takrat ugotovljeno, da je gibanje samomorov v tistem statističnem obdobju konstantno in se niti dviga niti ne pada. Leta 2017 smo s pomočjo SPS evidentirali le po en primer samomora in poskusa samomora policista, opazen pa je dvig števila samomorov v zadnjih treh letih oziroma od leta 2018 do 2020, ki je glede na prejšnje statistično obdobje, od leta 2009 do 2017, kljub vsemu le mejno statistično značilen oziroma za zadnje obdobje kljub vsemu še ne moremo govoriti o značilnem statističnem povečanju.

Podatki o vzročnosti samomorov v policiji za obdobje od leta 2017 naprej nam niso znani, saj niso dosegljivi.

Glede na način storitve samomora je od leta 2009 do 2016 od skupno 31 evidentiranih primerov prevladoval samomor z ustrelitvijo - 18 primerov ali $69,2 \%$, sledi samomor z obešanjem - trije primeri ali $11 \%$ ter zastrupitev s CO - dva primera ali 7 odstotkov (Blažina, 2017, str. 351). V obdobju od leta 2017 do 2020 prevladuje način storitve samomora z ustrelitvijo - pet primerov ali $62 \%$, dva samomora z obešanjem ali 25 $\%$, en samomor - skok z višine ali 12,5 \% (SPS, 2021). Za obravnavano skupno obdobje od leta 2009 do 2020 lahko ugotovimo, da je bilo za storitev samomora v $74,2 \%$ uporabljeno strelno orožje (23 primerov), v 16,1\% je bil samomor izveden z obešanjem (pet primerov), v 6,5 \% z zastrupitvijo s CO (dva primera) in v enem primeru (ali 3,2 \%) s skokom $\mathrm{z}$ višine. V statistiki nismo upoštevali poskusov samomora, ki smo jih zbrali le za obdobje od leta 2017 do 2020, in sicer sta bila dva poskusa samomora z ustrelitvijo, eden s hladnim orožjem in eden z zastrupitvijo $\mathrm{s}$

\footnotetext{
Hi-kvadrat ( $\chi 2$ ). Z navedeno statistično metodo smo ugotovili odvisnost ali neodvisnost (statistično odvisnost) različnih parametrov in kategorij primerjalnih skupin med seboj (statistično značilne razlike so podane, ko je rezultat p-vrednosti $<0,05)$.

${ }^{6}$ Statistično značilna vrednost je podana šele, ko je p-vrednost $<0,05$.
} 
tabletami. Glede na opisano lahko zaključimo, da v obdobju od leta 2009 do 2020 pričakovano prevladuje način storitve samomora z ustrelitvijo, skupaj 74,2 \%.

\section{UGOTOVITVE IN REZULTATI OPRAVLJENE RAZISKAVE}

$\mathrm{Na}$ podlagi opravljene analize statističnih podatkov smo ugotovili, da se statistika gibanja samomorov v policiji v obdobju od leta 2009 do 2020 postopoma povečuje (graf 2). Podatke o pojavnosti samomorov smo črpali iz že objavljene analize samomorilnosti v policiji od leta 2009 do 2016, v kateri so uporabljeni uradni podatki policije (Blažina, 2017). Ker ni na voljo uradnih podatkov, smo za izvedbo raziskave statistike in pojavnosti samomorilnosti v policiji uporabili in upoštevali tudi neuradne podatke Sindikata policistov Slovenije, in sicer za obdobje od leta 2017 do 2020. Podatki so predstavljeni v tabeli 2. Predvidevamo tudi, da se bo ob odsotnosti sprememb tak trend $\mathrm{v}$ prihodnosti še nadaljeval.

Ugotovili smo tudi, da je slovenska policija ustrezno sistemsko pripravljena na spoprijemanje s problematiko samomorilnosti v lastnih vrstah. Policistom so nenehno na voljo usposobljeni psihologi, ki so organizirani na policijskih upravah ali v posameznih večjih enotah, delujejo tudi SOS-telefon, mreža policijskih zaupnikov, vikar in predstavniki policijskih sindikatov. Posameznike, ki so samomorilno ogroženi, obravnava strokovna zdravstvena služba v okviru MNZ. Policija ima ukrepe strukturirane v lastnem Pravilniku o psihološki podpori uslužbencem policije (2013).

Ugotovili smo, da policija sistematično ne vodi podatkov o samomorih v lastni organizaciji in podatkov ne analizira, niti na tej podlagi ne izvaja ukrepov. Nekateri policisti, ki so samomorilno ogroženi in so že poskusili storiti samomor, lahko kljub temu še naprej posedujejo službeno orožje oziroma so s službenim orožjem samomor tudi dokončali.

Policija deloma upošteva domače in tuje aktualne smernice in ugotovitve, povezane s področjem samomorilnosti v policiji ali med splošno populacijo. Predvsem bi bilo smiselno upoštevati domače in tuje ugotovitve, povezane s povečano samomorilno ogroženostjo oseb, ki so že enkrat poskusile storiti samomor, in hkrati odtegniti sredstva, s katerimi bi samomor lahko izvedle oziroma ponovile (v tem primeru omejitev dostopa do službenega orožja). Prav tako bi bilo v luči Resolucije o nacionalnem programu duševnega zdravja 2018-2028 smiselno vzpostaviti evidenco samomorov v policiji, pripraviti lastni akcijski načrt ali pa vsaj izvajati terminske analize pojava samomorilnosti $\mathrm{v}$ policiji $\mathrm{z}$ določitvijo potrebnih preventivnih ukrepov in predvidenim gibanjem te problematike $\mathrm{v}$ prihodnosti.

Da bi preverili uspešnost in pripravljenost policije za spoprijemanje s problematiko samomorilnosti v lastnih vrstah, smo opravili tudi vzporedno raziskavo glede načina ukrepanja ob pojavu samomorilnosti v Slovenski vojski, vključno s primerjavo statističnih podatkov o številčnosti pojava samomorilnosti v obeh organizacijah. 
Ugotovili smo, da se Slovenska vojska s problematiko samomorov v svojih vrstah ukvarja sistemsko in na podlagi vnaprej predvidenih ukrepov, navedenih v posebnem akcijskem načrtu. Stanje na področju problematike samomorov se sproti spremlja, analizira in na tej podlagi se pripravljajo ustrezni ukrepi. Pričakovano je še nadaljnje upadanje števila samomorov v SV (graf 1).

Sklep Pri analizi stanja na področju samomorov v policiji smo ugotovili, da v splošni populaciji v Sloveniji količnik samomorilnosti rahlo upada, kar traja vse od osamosvojitve države. Enakemu trendu statistično sledi tudi količnik samomorilnosti v policiji. Zbrani podatki za obdobje od leta 2017 do 2020 (osem samomorov policistov in štirje poskusi), še posebej v letih od 2018 do 2020 (sedem samomorov, trije poskusi), pa kažejo na pogostejše primere samomorov v policiji. Pri zbiranju podatkov o številčnosti in okoliščinah storitve samomorov v policiji smo se že $\mathrm{v}$ uvodu srečali s težavo zaradi odsotnosti podatkov o samomorih v policiji. Policija in Ministrstvo za notranje zadeve jih ne zbirata in analizirata. Posledično se v policiji oziroma v zdravstveni službi ministrstva ${ }^{7}$ ukvarjajo $\mathrm{z}$ vsakim posamičnim primerom stiske policista posebej, podatkov pa statistično ne zbirajo in podatkov nimajo, kar izhaja iz odgovora Ministrstva za notranje zadeve (MNZ, 2019) in policije (MNZ Policija, 2019), ki samo povzema odgovor ministrstva. Oba dopisa smo prejeli v začetku priprav in zbiranja podatkov za izvedbo te analize. Kot razlog za odsotnost tovrstnih podatkov nam je ministrstvo $\mathrm{v}$ dveh ločenih odgovorih pojasnilo, da evidence samomorov $\mathrm{v}$ policiji na ministrstvu ne vodijo, podatki o samomorih $\mathrm{v}$ policiji pa niso del evidenc, ki jih ministrstvo vodi s področja kadrov, varstva pri delu in socialne varnosti (MNZ Policija, 2019). Ocenjujemo, da bi Ministrstvo za notranje zadeve ob upoštevanju 19. člena Zakona o varnosti in zdravju pri delu (ZVZD-1, 2011) že zdaj lahko izvajalo analitično dejavnost problematike, povezane s samomori v policiji, in sicer kot del celovite ocene tveganja. Pri tem bi bilo treba upoštevati omejitve, ki se nanašajo na varstvo osebnih podatkov v obravnavanih primerih, obenem pa je treba razumeti, da je zaradi majhnega števila primerov samomorov težko zagotoviti popolnoma anonimizirane podatke, ki bi bili pozneje predstavljeni v splošni in bolj poglobljeni analizi. Nasprotno prej opisanemu pa SV problematiko samomorilnosti v SV izvaja redno in sistematično, glede na vsebino lastnega akcijskega načrta, ki ima v prilogi navedene nosilce nalog, druge sodelujoče, naloge in konkretne roke izvedbe nalog (GŠSV, 2011). Podatke o samomorilnem vedenju vojakov črpajo iz zdravstvenih kartotek VZE (vojaških zdravstvenih enot) (GŠSV, 2011, str. 10).

Glede na ugotovljene vrzeli smo predlagali konkretne ukrepe, ki se smiselno nanašajo na Resolucijo o nacionalnem programu duševnega zdravja 2018-2028

MNZ za policijo izvaja kadrovske, finančne in logistične naloge podpore organa v sestavi, vključno z nalogami zdravja pri delu, kar je določeno v 3. členu Zakona o organiziranosti in delu v policiji (2013). 
(ReNPDZ18-28, 2018) $)^{8}$, ki bodo pomagali pri zmanjšanju in obvladovanju problema samomorilnosti v policiji ter bi obenem lahko postali primer dobre prakse obvladovanja in zmanjšanja samomorilnosti v varnostnih organih tudi v evropskem in svetovnem merilu. Predvsem gre za predlog za vzpostavitev tako imenovane evidence samomorov v slovenski policiji, doslednost pri omejevanju dostopa do orožja samomorilno ogroženim posameznikom, predvsem tistim, ki so samomor že poskušali storiti, ter pripravo in realizacijo terminsko omejenega operativnega načrta ukrepov. Posebno koordinacijsko telo v policiji bi na podlagi ustrezne pravne podlage lahko spremljalo gibanje samomorov ter izvajalo in vodstvu policije predlagalo učinkovitejše izvajanje preventivnih in kurativnih ukrepov za zaščito policistov. Pri primerjavi podatkov o številčnosti pojava samomorov med pripadniki SV in policije od leta 2015 do 2020 lahko ugotovimo, da sta obe populaciji približno enako ogroženi, primeri storitve samomorov pa niso konstantni, temveč se gibljejo od 0 do 3 primere na leto. Iz primerjave številčnosti storjenih samomorov v letih od 2015 do 2020 je razvidno, da je pri policiji trend pogostosti samomorov v vzponu, problematika izvršenih samomorov v SV pa se umirja in pada (graf 1). Vsekakor je pri omenjenem statističnem pregledu zaradi kratkega obdobja in majhnega števila evidentiranih primerov pri tolmačenju podatkov potrebna velika mera previdnosti, še posebej glede ocenjevanja prihodnjega gibanja te problematike $\mathrm{v}$ obeh populacijah. V obeh populacijah kot sredstvo izvršitve samomora prevladuje strelno orožje, obe populaciji pa sta glede številčnosti evidentiranih primerov izvršenih samomorov zelo blizu količniku samomorilnosti splošne populacije v Sloveniji.

Slovenska policija bi na podlagi uvedbe evidence samomorov, poglobljene analize vzročnosti in načrta izvedbe konkretnih ukrepov začela učinkoviteje izvajati preventivne ukrepe, pri tem pa obenem uskladila normativne vire, s katerimi bi predlagane nove ukrepe tudi formalno uredili. Pri tem bi kot primer dobre prakse lahko uporabila izsledke in akcijski načrt ukrepov, ki jih je glede zmanjšanja samomorilnosti med svojimi pripadniki že pripravila in jih tudi uspešno izvaja SV.

1. Barber, C., Berrigan, J. W., Sobelson-Henn, M., Myers, K., Staley, M., Azrael, D. et al., 2019. Analysis linking public safety and public health data for firearm suicide prevention in Utah. Health Affairs, 38(10), str. 1695-1701.

2. Blažina, B., 2017. The characteristics of suicide among Slovene police officers over the past seven decades. Revija za kriminalistiko in kriminologijo, 68(4), str. 333-358.

3. Costa, T., Passos, F., in Queirós, C., 2019. Suicides of male Portuguese police officers 10 years of national data. Crisis, 40(5), str. 360-364.

\footnotetext{
8 Strateški cilj Resolucije o nacionalnem programu duševnega zdravja 2018-2028 (ReNPDZ18-28, 2018) določa 15-odstotno zmanjšanje števila samomorov $v$ desetletnem obdobju kot prednostno področje preprečevanja samomora. Resolucija obenem določa potrebo po pripravi in sprejetju konkretnih podrejenih operativnih akcijskih načrtov ter specifične cilje: dvig ozaveščenosti in pismenosti na področju samomorilnosti, zgodnjo identifikacijo ogroženih oseb in zmanjševanje porabe alkohola, omejevanje sredstev za storitev samomora in zgodnjo identifikacijo ogroženih oseb. V pripravi je tudi triletni akcijski načrt za varovanje duševnega zdravja (NIJZ, 2020b), v katerem je kot prednostno področje definirano področje preprečevanje samomora.
} 
4. Grassi, C., Del Casale, A., Cucè, P., Kotzalidis, G. D., Pelliccione, A., Marconi, W. et al., 2019. Suicide among Italian police officers from 1995 to 2017. Rivista di Psichiatria 2019; 54(1), str. 18-23.

5. GŠSV, 2021. Podatki o spremljanju števila samomorov med pripadniki Slovenske vojske v obdobju 2015 do 2020, dopis št. 090-69/2021-3 z dne 30. 6. 2021.

6. GŠSV, 2011. Ukaz za implementacijo Akcijskega načrta za znižanje pogostosti pojavov samomorilnega vedenja v Slovenski vojski, št. 812-3/2011-410 z dne 14. 12. 2011.

7. GŠSV, 2011. Akcijski načrt za znižanje pogostosti pojavov samomorilnega vedenja na Ministrstvu za obrambo in v Slovenski vojski.

8. Huselja, A., 2017. Stres v uniformi. Ljubljana: Chiara.

9. Kolektivna pogodba za policiste, 2012. Uradni list RS (41/12, 97/12, 41/14 in 22/16).

10. Ministrstvo za notranje zadeve (MNZ), 2019. Dopis MNZ, številka 630-6/2019/3 (150212) z dne 7. 3. 2019. Ljubljana: Uprava za organizacijo in kadre.

11. Ministrstvo za notranje zadeve, Policija, 2021. Statistika: Poročila o delu policije za leta 2017-2020. https://www.policija.si/o-slovenski-policiji/statistika, 15. 6. 2021.

12. Ministrstvo za notranje zadeve, Policija, 2019. Samomori v slovenski policiji-odgovor. Dokument GPU PA, št. 630-40/2019/8 (262-02) z dne 17. 4. 2019.

13. Ministrstvo za obrambo, Slovenska vojska, 2021. Spremljanje števila samomorov med pripadniki SV v obdobju 2015 do 2020, dopis Sektorja za operativne zadeve Poveljstva sil SV, št. 090-69/2021-3 z dne 30. 6. 2021.

14. Nacionalni inštitut za javno zdravje (NIJZ), 2017. Zdravstveni statistični letopis 2017. https://www.nijz.si/sl/publikacije/zdravstveni-statisticni-letopis-slovenije-2017, 12. 5. 2021.

15. Nacionalni inštitut za javno zdravje (NIJZ), 2018. Zdravstveni statistični letopis 2018. https://www.nijz.si/sl/publikacije/zdravstveni-statisticni-letopis-2018, 10. 5. 2021.

16. Nacionalni inštitut za javno zdravje (NIJZ), 2020a. 10. september-Svetovni dan preprečevanja samomora. https://www.nijz.si/sl/10-september-svetovni-danpreprecevanja-samomora-preprecevanje-samomora-je-druzbena-naloga, 12. 5. 2021.

17. Nacionalni inštitut za javno zdravje (NIJZ), 2020b. Korak naprej v smeri večje dostopnosti storitev s področja duševnega zdravja: V Sloveniji trenutno v pripravi 3-letni akcijski načrt za varovanje duševnega zdravja. https://nijz.si/sl/korak-naprej-v-smerivecje-dostopnosti-storitev-s-podrocja-dusevnega-zdravja, 10. 5. 2021.

18. Nacionalni inštitut za javno zdravje (NIJZ), 2021. Svetovni dan preprečevanja samomora: Vletu 2020 blag upad števila samomorov. https://www.nijz.si/sl/svetovni-danpreprecevanja-samomora-v-letu-2020-blag-upad-stevila-samomorov, 15. 9. 2021.

19. Queirós, C., Passos, F., Bártolo, A., Marques, A. J., da Silva, C. F., Pereira, A., 2020. Burnout and stress measurement in police officers: Literature Review and a study with the operational police stress questionnaire. Frontiers of Psychology 11, str. 587.

20. Plemenitaš - Fuchs, N., 2003. Diplomsko delo Samomori v Slovenski vojski: Fakulteta za družbene vede. Ljubljana, http://dk.fdv.uni-lj.si/dela/Plemenitas-Fuchs-Natalija.PDF, 12. 5. 2021.

21. Pravila službe v Slovenski vojski, 2009. Uradni list RS, (84/09).

22. Pravilnik o psihološki pomoči in psihološki podpori uslužbencem policije, 2013. Uradni list $R S$, (51/13).

23. Resolucija o nacionalnem programu duševnega zdravja 2018-2028 (ReNPDZ18-28), 2018. Uradni list $R S$, (24/18).

24. Roškar, S., 2020. 10. september-Svetovni dan preprečevanja samomora. Preprečevanje samomora je družbena naloga. https://www.nijz.si/sl/10-september-svetovni-danpreprecevanja-samomora-preprecevanje-samomora-je-druzbena-naloga, 12. 5. 2021.

25. Sindikat policistov Slovenije (SPS), 2021. Podatki o samomorih v slovenski policiji, 12. 4. 2021. 
26. Violanti, J. M., Owens, S. L, McCaniles, E., Fekedulegn, D., Andrew, M. E., 2018. Law enforcement suicide: A review. Policing: An International Journal of Police Strategies \& Management, 42(2), str. 141-164.

27. Vlada RS, 2021. Duševno zdravje. https://www.gov.si/teme/dusevno-zdravje/, 21. 9. 2021.

28. Zakon o javnih uslužbencih (ZJU), 2007. Uradni list RS, (63/07, 65/08 in 69/08).

29. Zakon o organiziranosti in delu v policiji (ZDOPol), 2013. Uradni list RS, (15/13).

30. Zakon o spremembah in dopolnitvah zakona o obrambi, EVA 2020-1911-0009, str. 4, file:///C:/Users/brblazina/Downloads/o_ZObrOsn19062020\%20(3).pdf, 19. 6. 2021.

31. Zakon o službi v Slovenski vojski (ZSSloV), 2007. Uradni list RS, (68/07, 58/08).

32. Zakon o varnosti in zdravju pri delu (ZVZD-1), 2011. Uradni list RS, (43/11). 